\title{
Arab Women Reaching Out for the Forbidden
} Tree

\section{Zeynep Karaosman}

Department of English Language and Literature, İstanbul Aydın University, İstanbul, Turkey Email: zeynepkaraosman@gmail.com

\begin{abstract}
In the light of Joumana Haddad's I Killed Scheherazade: Confessions of an Angry Arab Woman, this paper aims to draw attention not only to the social identities and living conditions of today's Arab women but also to their struggle against the male oppression and gender inequality existing in every field of daily life. The article discusses Haddad's approach of metaphorically killing Scheherazade and possible alternatives. Throughout history women have been despised and made to live according to the roles that are designed and attached to them by the males. Although we have come a long way in the struggle of disposing the impositions, male-based values and recreating the social and personal identity of women, there are still millions of Arab women who are being deprived and restricted of their human rights in every field of life such as family, education and career.
\end{abstract}

Keywords-Anger, Arab Women, Identity, Patriarchy, Struggle.

\section{INTRODUCTION}

I've never been myself

I've never had a name

But I ran to my body and I named it

And from the border of perdition I cried:

Save me oh my 'I'...

(Maysoun Saqr Al Qasimi, qtd. in Haddad p.79)

This poem written by Emirati poet Maysoun Saqr Al Qasimi helps us visualize the subaltern positioning of today's Arab women. In spite of the remarkable diversity among its people, ranging from the Berber hill tribes to the Dubai city dwellers, a mix of social classes, ethnic groups, different religions, nationalities and linguistic communities, the gender system in the whole region is shaped by and works through the institutions of patriarchy which determine much of the social order. In other words, men's putative superiority to women is a tenet accepted in the society and woman is portrayed as naturally deficient and weak. In such a male-dominated society, what is harder than being a woman is being a rebellious woman, fighting against the oppression and trying to make herself heard. Amongst these women Joumana Haddad, an unapologetic feminist author from Lebanon, decides to "kill" Scheherazade, the heroine of literary fiction rooted in the famous Persian tales of 1001 Arabian Nights. This appears to be an extremely radical move, since Scheherazade is considered to be a feminist icon and a provocative role model representing not only a beautiful, charming and intellectual woman, but also a woman of great courage and willingness to save others. In her book, I Killed Scheherazade: Confessions of an Angry Arab Woman, Haddad kills one of the most admired literary characters in Arab culture because she believes that Scheherazade teaches women how to make concessions to their rights rather than teaching them resistance or rebellion.

Before reaching the point of killing Scheherazade, Haddad confesses that the stereotype of Arab woman, who is often imagined and portrayed as submissive, powerless, humiliated and ignored does apply, and sadly she is the ruling model of Arab women these days. However, in spite of this harsh reality, Haddad emphasizes that the 'other', self-sufficient Arab woman also does exist, and she needs and most importantly deserves to be noticed. Therefore, Haddad begins telling her stories as one of those atypical Arab women so as to show that the prevalent image of the typical Arab woman is not all wrong but rather incomplete.

\section{WOMEN'S POSITION IN THE ARAB SOCIETY}

Family lies at the core of both traditional and contemporary Arab society and in this basic unit, the place of woman is determined and restricted since the priority is given to the males. This hierarchical structure is justified in kinship terms. A woman becomes a part of the man's kin group through marriage which is symbolized by the adoption of his 
surname. In patrilinear tradition also their children take the father's surname. The wife is expected to respect and not to question his instructions. This position is complementary to that of the man, who is given all the authority over his kin, as well as the title of rabb al-ursa (lord of the family). The woman's position is also reflected in her title. Since the role reserved for women is that of mother and housewife, she gets the titles of aqila (tied), qarina (linked), and hirma (prohibited) (Rashad, Osman, \& Roudi-Fahimi, 2005). In the traditional Arab family, the accepted authority figure at the top of the pyramidal family structure is the provider of material goods, the breadwinner. This role, traditionally reserved for men often provides him with an unquestioning compliance with his instructions within the realm of family and respect from all family members and society (Barakat, 1993).

Working in and/or having a larger sphere of interaction than the immediate family, the father could be considered an intermediator between society and the family. The mother, on the other hand, takes on the role of the housewife, with the full responsibility of raising her kids in compliance with the norms of existing patriarchy. Within this patriarchal institution, male offspring is favoured, therefore; infertility of the wife or bearing a son is considered to be a "failure" and both of these so-called failures gives the man the right to get married to another woman.

It is important to note that the values of people also in the Arab world differ considerably between families or even between members of one family. But it is equally important to see that certain patterns are very widely shared. These patterns are reproduced through family practices as well as by heading down concepts. Honour is the gravest one among these concepts, as it defines one individual's sense of dignity, identity, and status in the community. The idea of family honour not only enhances the male power but also justifies it. By tying men's honour to women's behavior, having control over woman's sexuality and restricting her place in society and to some extent in working areas, becomes not only the man's right, but also his duty.

Working women in the Arab society suffer from a huge gap between men and women in terms of pay and participation rates. Traditional and conservative pressure restrain women from participating in the labour force. According to a survey conducted by Gallup (2012), about $67 \%$ of young Arab women stay out of the workforce, while it is $20 \%$ for men. This gender gap is generally consistent across all Arab countries. Moreover, because women are considered to be less powerful and influential in their social interaction, they mostly work in lower positions with lower payments as well as being overobserved. Therefore, women in the working area have less psychological safety than men do. The traditional perception in Arab countries, which asks women to merely devote themselves to the family as wives and mothers, not only affects their place in business life, but also limits their career opportunities and development (Metcalfe, 2007). Due to the high possibility of women quitting work when they get married or have children, investing in women's development is considered to be a waste of time and capital, which makes employers offer more opportunities of career development to men than to women (Doumato \& Posusney, 2003). Furthermore, in some Arab countries, women's working hours and the type of jobs that are suitable for women are not only determined by the social norms but also by law. Most Arab countries do not allow women to work at night and many restrict women from working in places where gender segregation may be violated (Sullivan, 2012). In Saudi Arabia, women are restricted from being appointed as judges (Saliba, 2014). In Jordan, Article 69 of the Labor Law specifies the works which are prohibited to women as well as the times during which women can work. Women are not allowed to work in dangerous environments and cannot work between the hours of eight at night and six in the morning, with minor exceptions (Peebles, Darwazeh, Ghosheh, \& Sabbagh, 2007). Mobility is another important factor affecting Arab women's work engagement. Whereas working abroad or in other cities is possible for men, it appears to be unreachable for most of the Arab women. As a result, they have to restrict their job search and career development to the places within walking or short commuting distance.

Due to all these imperious restrictions, many Arab women are pessimistic about building a career, which affects the ranking of women's education at all levels and fields of study. Even if laws and decrees in most of the Arab states provide educational opportunities for both sexes, coeducational schools are few in numbers and the majority of the schools are only for boys. It must also be noted that the education that girls receive is generally different from their male counterparts. Textbooks and the curriculums are mostly prepared to reinforce the gender roles determined by patriarchy, which teach women to fit in the domestic roles or the "accepted" professions. (Arab Human Development Report, 2005). There is also inequality between the two sexes on extra-curricular education like technical training, physical education, music and professional training. It can be seen that the 
participation of female students in those classes are neglected, particularly in coeducational schools. Likewise, most of the boys are seen to avoid participating in the home economics or sewing classes (Arab Human Development Report, 2005). The situation in higher education is not different either. Even if there is an increase in the number of female students at universities, most of the women are encouraged to study in departments such as literature, social sciences and the humanities, which are in low demand on the job market. On the other hand, the number of female students in the fields of engineering and industry is notably lower since such jobs are considered to be inappropriate for women. Moreover, the acceptance criterias of some universities are extremely biased against women. At the University of Kuwait, for instance, males are accepted in the engineering and petroleum departments on the basis of a grade point average of 69,9 out of 100 , while female students have to get an average of 83,5 for being accepted in the same departments (Arab Human Development Reports, 2003). In a nutshell, the issue of women's education in the Arab world is mostly about providing the "right" and "appropriate" kind of education in accordance with what is considered to be the needs of the society. Many governments and most of the intellectuals support the education of women, because from their point of view; an educated woman means an ideal wife, home keeper and mother. It is clear that her individual needs are not acknowledged since she is not even considered to be an individual.

Marriage also plays a central role in the consolidation of male in the Arab world. A woman is usually seen as an inferior being which is not only reflected but fixed in her legal position. Her rights are far more limited compared to man's rights. In most Arab countries, women other than man can only get married after getting the consent of a male relative or a judge. On the other hand, man can end the marriage contract even without the presence or without the knowledge of the woman herself (Würth, 2008 Under many contemporary legislations, such as Saudi Arabia (HRW 2019) there is no obligation for husbands to provide reasons for divorce while wives have to back their divorce files with legal grounds to get a divorce. Moreover, the husband gets exclusive rights such as demanding obedience from his wife. Interestingly, this legislation parallels the French civil code in place until 1938, where the husband had the legal obligation to protect his wife, while she legally owed him obedience in return. In Lebanon, there is even a law that includes a right of the husband to ask the police to force his wife back to their marital home (Würth, 2008). Furthermore, different non-conventional marriage forms, which are known as urfi, muta'a and messyar, still exist to satisfy men and have more control over women's lives These marriages are undertaken to avoid legal issues, high costs related to the wedding and dower or just to give an existing or planned sexual relationship the appearance of legitimacy in the realm of Islamic Law. Some families, especially in rural villages, opt for urfi marriages when the bride is too young to be legally married. In Muta'a, which is known as temporary marriage, the date upon which the marriage ends is specified on the marriage contract. Messyar, mainly practiced in Gulf countries, is an arrangement in which a man marries a woman without having any of the housing or financial responsibilities that a standard marriage would ask of him. This form of marriage is generally practiced by men who are marrying a second, third or fourth wife (Rashad, Osman, \& RoudiFahimi, 2005).

\section{ARAB WOMEN REACHING OUT FOR THE FORBIDDEN TREE}

Badreya whispered in her ear, "The price of freedom is high, Bodour, and there is no writing without freedom. Break your chains, Bodour, break free of your prison and reach out for the forbidden tree. If you eat from it, you will not die, for knowledge leads you to life and not to death. You will live forever (Nawal El Saadawi, Zeina p.162).

The quote emphasizes the role of struggle on the road to empowerment. Breaking chains and eating the forbidden apple stand metaphorically for becoming an agent in their own lives. To become a subject, one must become a rebel. Egyptian feminist writer Nawal El Saadawi, the author of this quote, is just one of many courageous Arab women raising their voices without making any concessions to their freedom, desires, struggles and dreams despite the high price they have to pay for it in the societies described in the last paragraph. Another one of these angry, passionate, strong and fearless women Joumana Haddad. Nourished by the fruit of knowledge, she expresses the urgent need of breaking loose from the control of oppressive patriarchy. In her autobiographical essay I Killed Scheherazade, Haddad rejects the norms of patriarchal Arab and more specifically Lebanese societies. All the more surprising is the fact that she gives her essay the title of a murder, not just any murder, but the murder of a 
feminist ikon. This radical fictional move can only be understood in terms of her literary criticism. She sharply criticizes the idea of the fictional character Scheherazade being a role model for Arab women, therefore; instead of lining up to praise her as many did before her, she thinks that it is time to "kill" Scheherazade, to make room for real heroines.

Joumana Haddad is an award-winning poet who writes sexually explicit poetry and the publisher of an erotic magazine called Jasad (meaning 'body'), which is absolutely out of ordinary in an Arab country. The first year she took her magazine to the Beirut book fair, she was threatened with rape, murder and stoning as well as being called debauched and immoral. Being a publisher of such a controversial erotic magazine in the Arabic language is not only startling the Arab world, but also surprises non-Arabs. One foreign journalist, who asked her how she had reached the point of publishing Jasad, revealed his presuppositions about Arab Women to be stereotypical and overgeneralizing, when he said that the reason for his question was that most of the West assumed that liberated women like her did not exist in Arab countries. Haddad states that she felt quite provoked by the journalist's question, but also could not immediately grasp the reasons for feeling this way. She turned these conflicting feelings and her initial irritation into words, words into stories that marked the beginning of a book full of confessions and a sharp criticis $m$.

As an Arab woman, born and raised in Beirut, Haddad wants to clarify that unlike the generalizing assumptions of many people raised in the West, there are also Arab women wearing whatever they like to wear, going wherever they wish to go and not afraid to say whatever they want to say. With this clear initial clarification, Haddad tries to confute the general opinion she Westerners appear to have about Arab women and wishes to offer a testimony on what being an Arab woman does and could mean today. This in mind one could expect a reactionary rectification of Western stereotypes of Arab women. Quite the contrary, Haddad underlines the fact that her book is actually an effort of self-criticism and it is mainly addressed to her fellow Arab citizens.

In the chapter, titled An Arab Woman Not Belonging Anywhere, Haddad tells us about her relationship with the city she was born in and grew up in. Haddad was only four and a half years old when the Lebanese civil war broke out. She describes that time as heavy and thick, almost like mud, during which the best years of her childhood and adolescence had been consumed. She accepts herself as a war-broken woman, yet she also adds that the war did not succeed in destroying her. On the contrary, it turned her into a fierce fighter, with an endless desire to live in joy and progress. Nevertheless, she cannot help thinking how different Arabs, especially women would be if they had not experienced all these horrible men-made wars;

War is men's business, they say. So losing loved ones must be women's, I assume. How much more serene, more concentrated on her own personal fights, would the Arab woman be today if she had not been forced, in so many countries, to occupy the position of the widowed wife or the orphaned daughter or the distressed mother and sister? (Haddad 2010, p.51).

Not only in Lebanon but also in most of the Arab countries such as Palestine, Iraq, Egypt, Syria, and Tunisia, women have been suffering from the menmade wars besides their personal fights and inequality. The wars which took lives, destroyed homes and families, turned the countries into a "factory of widows and orphans" (Haddad 2010, p.52). Haddad thinks that this is the reason why she does not feel she belongs to the city she was born in and she describes the city of Beirut as a woman who got lost and torn apart. By depicting Beirut as a woman, Haddad lets the city come to life. She gives her a female body that has suffered from wars and patriarchy and thereby reflects the experiences of the women living within it. Beirut has had her share of patriarchy just as every woman has. She satisfies the ego of a patriarchal society and comforts its needs during the daytime, while she turns to herself and feels her essence only when she is alone at nights. Therefore, the writer names her "the queen of contradictions" (Haddad 2010, p.56).

Where women don't even enjoy the right to pass their nationality on to their children, if they are married to a foreigner, among many other discriminative regulations, but do benefit from a special bank loan to get their boobs blown up and their noses sized down; Where girls from 'good families' are still expected to be virgins on their wedding night. Where guys are still looking for virgin girls from 'good 
families' to marry (Haddad 2010, p.57-

58).

The negation of basic rights based on a person's gender and the double standard and contradictions become tangible in the quote. Nawal El Saadawi even goes as far as to say that to erase these extreme inequalities, women or rather the concept of women would have to be erased entirely. "A better world is not possible without freeing the minds, bodies and most of all language of women" (El Saadawi 1931 as quoted by Haddad 2010, p.33)

In the next chapter, titled An Arab Woman Writing Erotic Poetry, Haddad, as the writer of sexually explicit poetry, says she had been in her mid-twenties when she used the word 'penis' in an Arabic poem for the first time. The reaction of her father - the same father who didn't let her out of the house alone and had hidden all the books that he thought to be dangerous on the highest shelves of his library, but had also been her number one fan up to then - was between disbelief and irritation. He would have preferred her using the word 'column' instead. However, Haddad had enough of using metaphors instead of the word itself while writing a prose poem about penis for a poetry magazine. Her dad opted for hiding the magazine away and praying that no one of the family would see it as could be perceived as revealing his daughter's 'scandalous hallucinations' (Haddad 2010, p.64).

Haddad does not give this anecdote because the penis is a must and great topic to write about or because she does not like metaphors, actually she loves images and knows well that they are a significant part of the poetic game. Her aim is to show her progress from freedom of thought to the freedom of expression and how hard it was for her. She began writing at the age of eleven, but only more than fifteen years later she dared to express her real ideas and convictions in Arabic. Her restraints on writing in Arabic are also reflected in the fact that she wrote her first book of poetry in French instead of Arabic. She gave this time of her writing career the title 'pre-penis era'.

In fact, when now I read my poetry from the 'pre-penis' era, I feel angry, ashamed and nauseated, because that era reminds me of how women have been deprived of expressing their bodies for so long in our culture. I feel angry because of the malicious castration that has been unjustly carried out on the Arabic language, and, consequently, on my use of it. And ashamed, and nauseated, by the number of sugary terms and metaphors I used to employ in order to hide my real self. It is not a coincidence that my first book of poetry was in French. I started by cowardly hiding in French in order to avoid confronting Arabic (Haddad 2010, p.64$65)$.

Ever since Haddad decided to free herself from the social boundaries and began to write explicitly about the body in Arabic, she has been asked and judged about why she chooses eroticism and the body as topics. Haddad explains it by saying that she writes about the body and sex, about her desires and needs, not because she wants to titillate her readers, as she is being accused of doing by some Arab critics, but simply because she does not separate her life from her writing. The need of explanations and justifications for such ridiculous questions is what irritates her the most. While that kind of polemic might sound pointless and superfluous in the West, the case is unfortunately so different in the Arab world. Arab writers, especially women, are deprived of freedom of expression. Censorship, which is ruthlessly applied is defined as 'an act of rape' by Haddad (2010, p.69).

All the double standards, all the deprivation, frustration and boundaries that I, and many other Arab writers, have witnessed and keep on witnessing, apply to women, as I've mentioned above, much more tyrannically than they apply to men. In many cases, they do not even apply to men at all. For in our dear old Arab world, men are allowed to talk rather unreservedly about their genitalia (not to mention using them unreservedly as well). They are allowed to talk about woman's genitalia too, as a free bonus. As for the woman, she has to content herself with being the blessed 'receiver' of male words, the passive subject of the male texts. For she was not born to express. Rather to BE expressed (Haddad, p.6970).

The act of rape is therefore constituted by the unilateral invasion of the female body and soul by men through words. Words that establish dominance in the discursive field and thereby limit the perception of the female body, phantasies and sexuality. 
The pursuit of knowledge and the appropriation of one's language are, as can be seen in the afore argument, central aspects of women's struggles in the Arab world. To more accurately get an idea of these struggles it is important to ask what it means to be a woman writer in the Arab world. The Arab world is where literary critics use the word of 'daring' to describe a woman writer who transgresses or writes about sex, while it is counted as completely normal for a man to write about the same subjects. Being a woman writer who writes without compromise in an Arab country is like facing the monster of prejudice, which is not easy at all. Haddad describes this situation as being swamped by 'a slew of patriarchal accusations' (Haddad 2010, p.73). These 'daring' women writers do deserve to be noticed, heard and acknowledged by the world for these women consider freedom as a vital necessity not as a luxury and they refuse to concede their right to choose to patriarchy. In 2006, Haddad started thinking about establishing a small publishing house of her own and editing a cultural magazine in Arabic. Of course, that magazine was not going to be a typical one, but a but rather different, strong and needed one. Haddad sees the body as the universe in which her own poetic language chose to express itself. On the other hand, most themes relating to the body are considered to be taboos in the Arab world, and accordingly the Arabic language has been unfairly deprived of the related words. Therefore, choosing the Body as topic and naming her magazine as JASAD didn't take her a long time. Haddad knew that the general public would not embrace the idea of her magazine as she knows well the Arab culture and its institutions which consider censorship to be a protector of values. Haddad claims that the Arab mind is in crisis and it wants everyone to be in crisis with it. She adds that questions are its worst enemy and people rather relied on the illusion of truth. The mind that applauds nudes by Westerners but calls the similar erotic art by Arab artists pornography or praises the Western writers that broke taboos in their works, but calls it decadence when an Arab cultural magazine publishes erotic poems, stories and texts. Haddad summarizes this double standard by saying; "We constantly and obsessively think about sex, but dare not talk about it" (Haddad 2010, p.91).

Haddad clearly encourages women to sustain who they really are without expecting any approval from men and without caring about internal or social obstacles. They are to be their own guide of their body, spirit and their essence. Neither the religious radicals nor the 'superficially radicals' (Haddad 2010, p.100), who consider women to be objects in a store window, should have a right to say a word on how women should live. In the Arab world, including Lebanon, the female stereotype dictated by patriarchal society, which expects woman to only do housework, take care of her husband and kids, still commonly exists. Haddad states that it hasn't been a long time since they got rid of single-sex schools. On the other hand, a female-only pink taxi service has been established in Lebanon, which she finds quite embarrassing. Just like the 'Barbie generation' (ibid.), this 'segregating girls'-taxi generation' (ibid.) represents the conditioned mode of behaviour in the Arab world, she claims. She also adds that the choice of the toy for a little girl and the boy has the same aim. While the girls are surrounded with dolls, the boys are surrounded with cars, soldiers, tanks and guns. Haddad gives an anecdote about experiencing such thing when she was little. Her uncle bought her a miniature kitchen including a washing machine and an iron for her birthday. She describes the feeling she had that moment as 'insulting' even if she was just eight years old. She was expected to conform to that female stereotype. Having shared this anecdote, Haddad wants to make it clear that being a housewife, taking care of her family is not 'insulting' for a woman as long as it is her choice. "I am all for a woman cooking, if cooking is her wish and decision. I am against a woman cooking if cooking is expected of her, and imposed on her, for the sole reason that she is a woman" (Haddad 2010, p.105).

Living in a society of stereotypes, Haddad is angry not only with men but also with women who admit the oppression and surrender. She harshly criticises these women for doing nothing to change this dark situation except complaining about it. While doing so, Haddad underlines that she is not generalising or being unfair to her sex as she is well aware of the fact that there are a lot of women experiencing horrible things in some radical parts of the Arab-Muslim world. One of these practices, for Haddad the most horrific one, is what they dare to name honour killings' (Haddad 2010, p.108). There are many women in Arab countries that are killed for engaging in pre-marital sex, for being raped, for asking for a divorce or to get married against their families' wishes. All these acts are considered as tarnishing the honour of the family and killing her is accepted as self-defence. Haddad gives Kifaya Husain, a sixteen- 
year-old Jordanian girl, as an example among many victims. She was lashed to a chair on 31 May 1994 by her thirty-two-year old brother before he slashed her throat. Her "crime" was being raped by her other brother.

Female genital mutilation of which the aim is to deprive women of their right to pleasure, or the prearranged marriage of little girls are just two other horrific practises applied to women in the Arab world today. In that point, Haddad criticises women especially the mothers who become the worst enemy of their kind. Mothers who keep silent to a rapist father, mothers that try to find husbands for their thirteen-year-old daughters or deprive them of education because they are to get married soon and also the mothers who raise their sons to fit perfectly into the patriarchal society. Therefore, Haddad is calling on women to act for a solution rather than just complaining about their suffering. Even a small act in their daily reality can make a change.

Haddad also argues that women should not ask for equality since it makes her the asker and the male the grantor. Instead of this, we should live and behave as if it is a given fact. She agrees that it may not always be applicable especially within discriminative legal frameworks, yet we can apply it in many parts of our daily lives, which can influence laws and constitutions in the long run.

The true issue is for her to regain her stolen, confused identity. Regaining this unknown, kidnapped identity, this compromised being that has been distorted under various forms of fear, conditioning and frustration, is the hardest battle that a woman must fight, and win. [...] As for the insultingly easy gains that are given to women as consolation prizes or as anaesthesia or bribes, these are landmines concealing treacherous compromises; so, we'd better not accept them. Either everything. Or nothing. We need to win (or lose, evidently) our battles as ourselves, without conditions, alterations, deals or compromises to our womanhood (Haddad 2010, p.111-112).

It's true that Haddad is an Arab woman writer, which may sound as a rare and so 'zoo attraction' (Haddad 2010, p.137) figure. However, she again emphasizes that she is not the only one. There are great Arab women intellectuals, novelists, artists, poets, playwrights and directors who manage to make a difference in spite of the challenges, obstacles and threats they face. Therefore, we need to dig deeper and tear off the generalising, sensationalist skin in order to reach for what's beyond the glistening surface since there are many different models and textures of 'veils' in the Arab world;

There's the veil of denial; the veil of self-deception; the veil of compromise; the veil of the exotic label; the veil of the biased political message; the veil of the distorted view and extrapolation; the veil of apprehension and fear; the veil of the narrow-minded judgment; and, most dangerously, the veil of the false, media-fabricated symbol ... (Haddad 2010, p.138)

Scheherazade, Haddad's title character, the heroin of The Arabian Nights and feminist icon in the Arab world, could be blamed for being too compromising, self-deceiving, exotic and her literary reception and glorification could be seen as the "false, mediafabricated veil" (ibid.). After all the confessions and autobiographical anecdotes, Haddad kills Scheherazade and explains the reason of that metaphorical murder. Scheherazade willingly began a relationship with a king that had murdered every lover before her after having sex with them. In order to save herself from death, she began telling him stories that were so thrilling that the king could not kill her since he was always eager to hear the next part of the story. These almost legendary cliffhangers saved her life long enough for the king to fall in love with her and eventually stop killing women routinely. Scheherazade is accepted as an educated, creative and intelligent woman and widely admired by all women worldwide, especially the Arab ones. However, Haddad, who actually does love reading and rereading The Arabian Nights, believes that the story gives a wrong message to women. She argues that, contrary to popular opinion, Scheherazade does not teach women resistance and rebellion. It rather teaches them concession and negotiation over their basic rights. "Persuade men, give them the things you have, and they want, and they'll spare you" (Haddad 2010, p.142). Therefore, it is all about persuading and pleasing men whether by a story as Scheherazade did or a nice meal, a pair of silicone tits or whatever he could imagine. Haddad simply says that persuading is not resisting. Actually, it is not Scheherazade that she is judging as she was just a poor lady trying to save 
herself from a savage who had beheaded one thousand women. What Haddad can't stand anymore is the fact that people, especially in the West, see Scheherazade as a heroine and moreover the symbol of Arab cultural female opposition and struggle against the injustice, cruelty and discrimination of men. That's the reason why Haddad decided to kill her.

She also adds that it was not solely her who pulled off this slaughter and actually she had many accomplices - whether hostile or encouraging: She killed her with the hands of all the men that tried to slash her throat and with the hands of all the women who made her believe that it is normal to have her throat slashed by a man. She killed with the hands of all the men and women who wanted her to sacrifice a part of herself so as not to have her throat slashed. Haddad killed Scheherazade with the hands of every woman treated like a delicious piece of meat in magazines, movies, on TV screens as well as in real life. She killed her with the hands of every man being laughed at by his macho friends for treating women decently. Haddad killed Scheherazade with the hands of her math teacher in fourth grade who tried to convince her that boys were good with numbers and girls with cooking. In addition to many others, this angry Arab woman puts Lilith, a strong feminist character from Sumerian, Arameic and Jewish Mythology, at the end of her list of possible role models. She states that she killed Scheherazade with the hands of Lilith who is her seed, root, earth and truth and makes it clear that the anger and the desire to live her life freely are so strong that nothing can stop her anymore.

Yes, I killed Scheherazade. I killed her in me. And I am quite determined to kill everything and everyone that even remotely looks or behaves like her in my unconscious, imagination and mind. So her sisters, daughters, granddaughters and all her descendants had better close down the concessions' business, or stay away, far away from me. For there's an angry Arab woman out there. She's got her own 'notintended-for-negotiation' stories, her own 'not-granted-by-anybody' freedom and life, and the perfect murder weapon. And there's no stopping her now (Haddad 2010, p.147)

\section{CONCLUSION}

In conclusion it can be said that yes, Haddad and others killed Scheherazade and no, this is not another femicide. The metaphorical murder can be deciphered as lifting "the veil of the false, media-fabricated symbol" of Scheherazade. The literary and cultural tradition in which Scheherazade has been perceived and in which she has been stylized as the symbol of resistance and the feminist role model per se is flawed and dangerous since it perpetuates patriarchal traditions. Therefore, it must change. It seems rather difficult to kill a literary reception all the more so, if this reception is hundreds of years old. Fossilized, hardened images need radical actions to be shaken. Killing Scheherazade, makes it possible for the reader to think beyond Scheherazade and open the own horizon to all the other magnificent feminist Arab women characters, fictional and non-fictional. Throughout history women have often been subjected to unfair and tyrannical treatment by the patriarchal systems existing all around the world. The struggle of women to live in a society where they are not oppressed but valued, recognized and respected, and where they don't need to fight for their basic human rights such as receiving education, joining the labour force and taking part in public life with their own decisions has been going on for centuries. Of course, comparing today with the past centuries, we can't deny the great strides that women have made in the fight for gender equality. However, we shouldn't also ignore the fact that the world is not made up of European countries and in different regions, there are hundreds of millions of women still living in the era lagging far behind the 21st century. The case in the Arab world, which spreads over twenty-two countries, is not bright either as the identities and roles of woman are determined by the institutions of patriarchy and women are systematically oppressed. As Haddad states in her book, this grim reality has to be noticed, but at the same time the angry Arab women resisting against patriarchy instead of bending down must be heard and acknowledged. And who knows, maybe in a world where we acknowledge the other voices, some of which were introduced in this article, maybe we could even resurrect Scheherazade. 


\section{REFERENCES}

[1] Abu-Odeh, L. (2010). Honor Killings and the Construction of Gender in Arab Societies. Retrieved from scholorship.law.georgetown:

https://scholarship.law.georgetown.edu/cgi/viewcontent.cgi ?article $=2644 \&$ context $=$ facpub

[2] Arab Human Development Report. (2005). Towards the Rise of Women in the Arab World. AHDR.

[3] Arab Human Development Reports. (2003). The State of Women in the Arab World. AHDR.

[4] Arnold, T. (2013, May 24). The National Business. Retrieved February 18, 2018, from https://www.thenational.ae/business/gender-pay-gap-inmiddle-east-between-20-40-1.317728

[5] Barakat, H. (1993). The Arab World; Society, Culture and State. Retrieved from Intersci: http://intersci.ss.uci.edu/wiki/eBooks/MidEast/BOOKS/Th e\%20Arab\%20World\%20Barakat.pdf

[6] Edemariam, A. (2010, August 21). Joumana Haddad: 'I live in a country that hates $m e^{\prime}$. Retrieved from The Guardian:

https://www.theguardian.com/theguardian/2010/aug/21/jou mana-haddad-interview

[7] Gallup. (2012). After the Arab Uprisings: Women on Rights, Religion, and Rebuilding. Washington: Gallup.

[8] Haddad, J. (2010). I Killed Scheherazade, Confessions of an Angry Arab Woman. Beirut: Dar al Saqi.

[9] Joseph, S. (1994). Gender \& Family in the Arab World. MERIP, 4(4).

[10] Karaosman, Zeynep (2018). Comparision of Virginia Woolf and Joumana Haddad As Angry Women

[11] Kurdar, S. (2004). Education, Gender and Cross-Cultural Experience with Reference to Elite Arab Women. Retrieved from

ora.ox.ac.uk: https://ora.ox.ac.uk/objects/uuid:db8d8e68-d8df-4cad-

$97 \mathrm{~d} 3-$

81fd3f4e939c/download_file?file_format=application/pdf \&safe_filename=602336265.pdf\&type_of_work=Thesis

[12] Mazloum, N. (2017, November 03). Joumana Haddad wants a 'more humane Lebanon', so she's running for parliament. Retrieved from Stepfeed.

[13] Metcalfe, B. D. (2007, January 11). Gender and Human Resource Management in the Middle East. Retrieved March 01, 2018, from Researchgate.net: https://www.researchgate.net/publication/254299960_Gend er_and_human_resource_management_in_the_Middle_Eas $\mathrm{t}$

[14] Middle East and North Africa Social and Economic Development Group. (2009). The Status \& Progress of Women in the Middle East \& North Africa. Retrieved from siteresources.worldbank:

http://siteresources.worldbank.org/INTMENA/Resources/ MENA_Gender_Compendium-2009-1.pdf

[15] Peebles, D., Darwazeh, N., Ghosheh, H., \& Sabbagh, A. (2007). Factors affecting women's participation in the private. Retrieved from Almanar.jo: http://www.almanar.jo
[16] Rashad, H., Osman, M., \& Roudi-Fahimi, F. (2005, September). Marriage in the Arab World. Retrieved from Assets:

https://assets.prb.org/pdf05/M arriageInArabWorld_Eng.pdf

[17] Saadawi, N. E. (2011). Zeina. (A. Nowaira, Trans.) Beirut: Saqi.

[18] Saliba, I. (2014, November 14). Saudi Arabia: Women Not Allowed to Perform Notary Duties. Retrieved March 15, 2018, from Library of Congress: http://www.loc.gov/law/foreign-news/article/saudi-arabiawomen-not-allowed-to-perform-notary-duties/

[19] Sullivan, K. (2012, November 13). Saudi Arabia struggles to employ its most-educated women. Retrieved March 04, 2018, from The Independent: https://www.independent.co.uk/news/world/middleeast/saudi-arabia-struggles-to-employ-its-most-educatedwomen-8312035.html

[20] Würth, A. (2008, December). Women's Rights in the Arab World. Retrieved from Menengage: http://menengage.org/wpcontent/uploads/2014/06/womens-rights-arab-world2008.pdf

[21] Yaqoob, T. (2012, June 1). Joumana Haddad: 'Arab women have been brainwashed'. Retrieved April 12, 2018, from The Independent: https://www.independent.co.uk/news/world/middleeast/joumana-haddad-arab-women-have-beenbrainwashed-7804762.html 